\title{
KUAT TEKAN MORTAR DAN SILINDER BETON PADA PERPADUAN MATERIAL LOKAL PASIR SAMBOJA DENGAN PASIR PALU
}

\section{CONCRETE MORTAR AND CYLINDER COMPRESSIVE STRENGTH WITH THE COMBINATION OF LOCAL MATERIAL OF SAMBOJA SAND AND PALU SAND}

\author{
Karmila Achmad $^{1 *}$, Sunarno ${ }^{2}$ \\ ${ }^{1,2}$ Teknik Sipil-Politeknik Negeri Balikpapan \\ Jl. Soekarno Hatta Km.08, Balikpapan \\ email: karmila.achmad@poltekba.ac.id
}

\begin{abstract}
SambojaSand is Balikpapan local material which is relatively inexpensive but it is not widely used fora concrete mixturein Balikpapan. This because the material has very fine grains, which resulted in this type of sand does not fall into the 4 zones of fine aggregate, which is a requirement for concrete mixture. Therefore, to use Samboja Sand, it needs to be combined with other types of sand that has a slightly coarse grain.This research aims to obtain physical properties of local fine aggregate in Balikpapan in concrete mixture and to obtain the optimal proportion of local fine aggregate in terms of the concrete compressive strength. In this study, 66 mortar and 66 cylinders of concrete were formed with various percentage of Samboja Sand as the fine aggregate of the concrete mixtures. The result shows that the proportion of Samboja sand that meets the fine aggregate criteria in the concrete mixture is below $70 \%$ with 1.64 approaching zone 4 (slightly fine sand). The test object P50 with proportion of $50 \%$ Palu sand and 50\% Samboja sand produced the highest concrete compressive strength at age 28-day that is 31,33 MPa-the increment of the compressive strength equal to 7,11\% to S100. Considering the trend of compressive strength, P50 and P60 provide the highest compressive strength trend.
\end{abstract}

Keywords: Compressive strength, Mortar, Palu sand, Samboja sand, Concrete cylinder

\begin{abstract}
Abstrak
Pasir Samboja merupakan material lokal Balikpapan yang relatif murah dan belum banyak digunakan dalam campuran beton oleh masyarakat Balikpapan. Hal ini karena material ini memiliki butiran yang sangat halus, yang mengakibatkan jenis pasir ini tidak masuk dalam ke 4 zona agregat halus yang merupakan syarat dalam campuran beton. Sehingga dalam penggunaannya pasir Samboja perlu dipadukan dengan jenis pasir lainnya yang memiliki butiran agak kasar. Tujuan penelitian untuk mendapatkan sifat fisik agregat halus lokal di Balikpapan dalam campuran beton dan mendapatkan proporsi paduan agregat halus lokal Balikpapan yang optimal ditinjau dari besarnya Kuat Tekan Beton. Dalam penelitian ini ada 66 mortar dan 66 silinder beton dengan variasi persentase pasir Samboja dalam agregat halus campuran beton. Hasil yang diperoleh menunjukan bahwa proporsi pasir Samboja yang memenuhi kriteria agregat halus dalam campuran beton adalah dibawah 70\% dengan MHB 1,64 mendekati zona 4 (pasir Agak Halus). Benda uji P50 dengan proporsi pasir Palu sebesar 50\% dan pasir Samboja sebesar $50 \%$ memberikan nilai kuat tekan beton terbaik pada umur 28 hari yaitu 31,33 MPa dengan peningkatan kuat tekan sebesar $7,11 \%$ terhadap S100 dan jika ditinjau dari tren kuat tekan yang terjadi adalah perpaduan pasir Palu dan pasir Samboja memberikan nilai yang baik pada P50 dan P60.
\end{abstract}

Kata kunci: Kuat Tekan, Mortar, Pasir Palu, Pasir Samboja dan Silinder Beton 


\section{PENDAHULUAN}

Beton merupakan material komposit yang tersusun dari agregat yang terselimuti oleh campuran semen dan air. Agregat menempati $70-75 \%$ dari total volume beton, maka kualitas agregat sangat berpengaruh terhadap kualitas beton. Dengan agregat yang baik, beton dapat dikerjakan (workable), kuat, tahan lama (durable), dan ekonomis. Secara umum, agregat dapat dibedakan berdasarkan ukurannya, yaitu agregat kasar dan agregat halus.

Penelitian sebelumnya tentang matrial lokal Kalimantan Timur adalah penelitian pasir Kandilo dari Tanah Grogot yang menunjukan bahwa pasir Kandilo memiliki karakteristi yang mendekati pasir Palu [1]. Pasir Samboja sendiri merupakan material lokal Balikpapan yang relatif murah dan belum banyak digunakan dalam campuran beton oleh masyarakat Balikpapan [2]. Penelitian pendahuluan tentang pasir Samboja berupa pemanfaatan pasir Samboja sebagai campuran beton normal telah dilakukan dengan menggunakan perbandingan modulus halus butir pasir samboja dalam campuran beton normal, dan hasil yang diperoleh mutu beton dengan pasir Samboja memiliki kekuatan yang baik[3]. Namun material ini memiliki butiran yang sangat halus, yang mengakibatkan jenis pasir ini tidak masuk dalam 4 zona pasir yang memenuhi syarat dalam campuran beton [2]. Sehingga pasir Samboja perlu dipadukan dengan jenis pasir lainnya yang memiliki butiran agak kasar.

Tujuan umum penelitian ini adalah: Mendapatkan sifat fisik agregat halus lokal di Balikpapan dalam campuran beton dan mendapatkan proporsi paduan agregat halus lokal Balikpapan yang optimal ditinjau dari besarnya Kuat Tekan Beton.

\section{METODE PENELITIAN}

Metode penelitian menjelaskan rancangan kegiatan, ruang lingkup atau objek, bahan dan alat utama, tempat, teknik pengumpulan data, definisi operasional variabel penelitian, dan teknik analisis.

Material agregat yang digunakan dalam penelitian ini adalah kerikil Palu dan 2 jenis agregat halus yaitu pasir Palu dan pasir Samboja sebagai material lokal. Peninjauan yang dilakukan berupa perhitungan modulus halus butir agregat halus, uji tekan mortar dan silinder beton.

Tabel 1 Rincian Benda Uji

\begin{tabular}{|c|c|c|c|}
\hline \multirow{2}{*}{$\begin{array}{c}\text { Jenis } \\
\text { variasi } \\
\text { benda uji }\end{array}$} & \multicolumn{2}{|c|}{ Jumlah Benda Uji } & \multirow{2}{*}{$\begin{array}{c}\text { Kode } \\
\text { Penamaan }\end{array}$} \\
\hline & Mortar & Silinder & \\
\hline $\begin{array}{l}\text { Pasir } \\
(100 \% \\
\text { palu) }\end{array}$ & 6 & 6 & $\begin{array}{l}\text { 1P100- } \\
6 \mathrm{P} 100\end{array}$ \\
\hline $\begin{array}{l}\text { Pasir }(90 \% \\
\text { palu+ } 10 \% \\
\text { samboja) }\end{array}$ & 6 & 6 & $\begin{array}{l}1 \mathrm{P} 90- \\
6 \mathrm{P} 90\end{array}$ \\
\hline $\begin{array}{l}\text { Pasir }(80 \% \\
\text { palu+ } 20 \% \\
\text { samboja) }\end{array}$ & 6 & 6 & $\begin{array}{l}\text { 1P80 - } \\
6 \mathrm{P} 80\end{array}$ \\
\hline $\begin{array}{l}\text { Pasir }(70 \% \\
\text { palu+ } 30 \% \\
\text { samboja) }\end{array}$ & 6 & 6 & $\begin{array}{l}1 \mathrm{P} 70- \\
6 \mathrm{P} 70\end{array}$ \\
\hline $\begin{array}{l}\text { Pasir }(60 \% \\
\text { palu+ } 40 \% \\
\text { samboja) }\end{array}$ & 6 & 6 & $\begin{array}{l}1 \mathrm{P} 60- \\
6 \mathrm{P} 60\end{array}$ \\
\hline $\begin{array}{l}\text { Pasir }(50 \% \\
\text { palu+ } 50 \% \\
\text { samboja) }\end{array}$ & 6 & 6 & $\begin{array}{l}\text { 1P50- } \\
6 \mathrm{P} 50\end{array}$ \\
\hline $\begin{array}{l}\text { Pasir (40\% } \\
\text { palu+ } 60 \% \\
\text { samboja) }\end{array}$ & 6 & 6 & $\begin{array}{l}1 \mathrm{~S} 60- \\
6 \mathrm{~S} 60\end{array}$ \\
\hline $\begin{array}{l}\text { Pasir }(30 \% \\
\text { palu+ } 70 \% \\
\text { samboja) }\end{array}$ & 6 & 6 & $\begin{array}{l}1 S 70- \\
6 S 70\end{array}$ \\
\hline $\begin{array}{l}\text { Pasir }(20 \% \\
\text { palu+ } 80 \% \\
\text { samboja) }\end{array}$ & 6 & 6 & $\begin{array}{l}1 \mathrm{~S} 80- \\
6 \mathrm{~S} 80\end{array}$ \\
\hline $\begin{array}{l}\text { Pasir (10\% } \\
\text { palu+ } 90 \% \\
\text { samboja) }\end{array}$ & 6 & 6 & $\begin{array}{l}1 \mathrm{~S} 90- \\
6 \mathrm{~S} 90\end{array}$ \\
\hline $\begin{array}{l}\text { Pasir } \\
(100 \% \\
\text { samboja) }\end{array}$ & 6 & 6 & $\begin{array}{l}1 \mathrm{~S} 100- \\
6 \mathrm{~S} 100\end{array}$ \\
\hline $\begin{array}{l}\text { Total } \\
\text { benda uji }\end{array}$ & 66 & 66 & \\
\hline
\end{tabular}

Tabel 1 menunjukan rincian benda uji. Variasi yang digunakan adalah persentase 
dari pasir Samboja dalam campuran agregat halus pasir Palu dan pasir Samboja.

Tahapan penelitian yang dilakukan adalah uji bahan, mix design, pembuatan benda uji, perawatan benda uji, uji tekan, analisa dan kesimpulan.

\section{HASIL DAN PEMBAHASAN}

Bagian ini menyajikan hasil penelitian. Hasil penelitian dapat dilengkapi dengan tabel, grafik (gambar), dan/ataubagan. Bagian pembahasan memaparkan hasil pengolahan data, menginterpretasikan penemuan secaralogis, mengaitkan dengan sumber rujukan yang relevani hasil pemeriksaan gradasi agregat halus diperoleh nilai Modulus Halus Butir pasir Samboja adalah 1,2 sehingga tidak memenuhi persayaratan agregat halus yang dapat digunakan dalam campuran beton. Hal ini menunjukakan bahwa pasir Samboja termasuk dalam kategori pasir sangat halus [4]. Sehingga dalam penelitian ini dilakukan perhitungan Modulus Halus Butir (MHB) dalam setiap persentase campuran benda uji yang digunakan. Hasil perhitungan MHB yang diperoleh seperti pada tabel 2 .

\begin{tabular}{|c|c|c|}
\hline \multicolumn{3}{|c|}{ Tabel 2.MHB Agregat Halus } \\
\hline $\begin{array}{l}\text { Jenis variasi } \\
\text { benda uji }\end{array}$ & MHB & $\begin{array}{c}\text { Zona } \\
\text { Agregat } \\
\text { Halus }\end{array}$ \\
\hline Pasir (100\% palu) & 2,67 & Zona 2 \\
\hline $\begin{array}{l}\text { Pasir }(90 \% \text { palu+ } \\
10 \% \text { samboja) }\end{array}$ & 2,53 & $\begin{array}{l}\text { Mendekati } \\
\text { zona } 2\end{array}$ \\
\hline $\begin{array}{l}\text { Pasir }(80 \% \text { palu+ } \\
20 \% \text { samboja })\end{array}$ & 2,38 & Zona 3 \\
\hline $\begin{array}{l}\text { Pasir }(70 \% \text { palu+ } \\
30 \% \text { samboja })\end{array}$ & 2,23 & Zona 3 \\
\hline $\begin{array}{l}\text { Pasir }(60 \% \text { palu+ } \\
40 \% \text { samboja })\end{array}$ & 2,08 & $\begin{array}{l}\text { Mendekati } \\
\text { zona } 3\end{array}$ \\
\hline $\begin{array}{l}\text { Pasir }(50 \% \text { palu+ } \\
50 \% \text { samboja })\end{array}$ & 1,94 & $\begin{array}{l}\text { Mendekati } \\
\text { zona } 3\end{array}$ \\
\hline $\begin{array}{l}\text { Pasir ( } 40 \% \text { palu+ } \\
60 \% \text { samboja) }\end{array}$ & 1,79 & $\begin{array}{l}\text { Mendekati } \\
\text { zona } 3\end{array}$ \\
\hline $\begin{array}{l}\text { Pasir ( } 30 \% \text { palu+ } \\
70 \% \text { samboja) }\end{array}$ & 1,64 & $\begin{array}{l}\text { Mendekati } \\
\text { zona } 4\end{array}$ \\
\hline $\begin{array}{l}\text { Pasir (20\% palu+ } \\
80 \% \text { samboja) }\end{array}$ & 1,49 & $\begin{array}{l}\text { Mendekati } \\
\text { zona } 4\end{array}$ \\
\hline $\begin{array}{l}\text { Pasir ( } 10 \% \text { palu+ } \\
90 \% \text { samboja) }\end{array}$ & 1,35 & $\begin{array}{l}\text { Mendekati } \\
\text { zona } 4\end{array}$ \\
\hline $\begin{array}{l}\text { Pasir } \\
\text { samboja })\end{array}$ & 1,2 & $\begin{array}{l}\text { Mendekati } \\
\text { zona } 4\end{array}$ \\
\hline
\end{tabular}

Berdasarkan syarat maka modulus halus butir maka persentase pasir Samboja yang dapat digunakan paling banyak adalah $70 \%$. Namun jika dilihat dari zona agregat maka persentase pasir Samboja yang dapat digunakan paling banyak adalah $60 \%$.

Benda uji yang dibuat berdasarkan hasil mix design yang mengacu pada SNI 032843-2000 tentang tata cara pembuatan rencana campuran beton normal [5].

Hasil pengujian mortar dapat dilihat pada tabel 3 .

Tabel 3.Hasil Uji Tekan Mortar

\begin{tabular}{|c|c|c|c|c|}
\hline \multirow[b]{2}{*}{$\begin{array}{l}\text { Bend } \\
\text { a Uji }\end{array}$} & \multicolumn{2}{|c|}{$\begin{array}{l}\text { Umur } 14 \\
\text { hari }\end{array}$} & \multicolumn{2}{|c|}{ Umur 28 hari } \\
\hline & $\begin{array}{c}\text { Kuat } \\
\text { Tekan } \\
\text { Penguji } \\
\text { an } \\
\text { (MPa) }\end{array}$ & $\begin{array}{c}\text { Pening } \\
\text { katan } \\
\text { Kuat } \\
\text { Tekan } \\
(\%)\end{array}$ & $\begin{array}{c}\text { Kuat } \\
\text { Tekan } \\
\text { Pengujian } \\
(\mathrm{MPa})\end{array}$ & $\begin{array}{c}\text { Pening } \\
\text { katan } \\
\text { Kuat } \\
\text { Tekan } \\
(\%)\end{array}$ \\
\hline P100 & 60,61 & 60,01 & 56 & $-13,41$ \\
\hline P90 & 49,24 & 30 & 42,67 & $-34,02$ \\
\hline P80 & 45,45 & 20 & 66 & 2,06 \\
\hline P70 & 46,97 & 24 & 51,33 & $-20,63$ \\
\hline P60 & 48,48 & 28 & 50,67 & $-21,65$ \\
\hline P50 & 48,48 & 28 & 60 & $-7,22$ \\
\hline S60 & 51,52 & 36 & 66 & 2,06 \\
\hline S70 & 40,15 & 6 & 59,33 & $-8,26$ \\
\hline S80 & 42,42 & 12 & 53,33 & $-17,54$ \\
\hline S90 & 39,39 & 4 & 60 & $-7,22$ \\
\hline S100 & 37,88 & - & 64,67 & - \\
\hline
\end{tabular}

Dari hasil uji tekan mortar umur 28 hari maka diperoleh nilai kuat tekan terbesar adalah untuk benda uji S60 yaitu benda uji dengan persentase pasir Palu adalah $60 \%$ dan pasir Samboja 40\%. Besar kuat tekan yang dihasilkan adalah $66 \mathrm{MPa}$ dengan peningkatan kuat tekan sebesar 2,06\% terhadap benda uji S100 (benda uji dengan $100 \%$ pasir Samboja tanpa pasir Palu). Nilai ini sama besarnya dengan nilai kuat tekan mortar untuk benda uji P80, yaitu benda uji dengan persentase pasir Palu adalah 20\% dan pasir Samboja $80 \%$.

Nilai kuat tekan rata-rata beton umur 14 hari adalah 60,61 MPa; 49,24 MPa; 45,45 $\mathrm{MPa}$; 46,97 $\mathrm{MPa}$; 48,48 $\mathrm{MPa}$; 48,48 MPa; 51,52 MPa; 40,15 MPa;42,42 MPa; 39,39 $\mathrm{MPa}$ dan 37,88 MPa masing-masing untuk 
benda uji mortar P100, P90, P80, P70, P60, P50, S60, S70, S80, S90 dan S100.

Dengan persentase peningkatan kuat tekan terhadap benda uji S100 yaitu mortar dengan pasir Samboja $100 \%$ pada umur beton 14 hari adalah $4 \%$; $12 \%$; $6 \%$; $36 \%$; $28 \%$; $28 \%$; $24 \%$; $20 \%$; $30 \%$ dan $60,01 \%$ masing-masing untuk benda uji mortar S90, S80, S70, S60, P50, P60, P70, P80, P90 dan P100.

Dari tabel 3 dapat dilihat besar nilai kuat tekan rata-rata mortar umur 28 hari adalah 56 $\mathrm{MPa}$; 42,67 MPa; $66 \mathrm{MPa} ; 51,33 \mathrm{MPa}$; 50,67 $\mathrm{MPa} ; 60 \mathrm{MPa} ; 66 \mathrm{MPa} ; 59,33 \mathrm{MPa} ; 53,33$ $\mathrm{MPa}, 60 \mathrm{MPa}$ dan 64,67 MPa masing-masing untuk benda uji mortar P100, P90, P80, P70, P60, P50, S60, S70, S80, S90 dan S100.

Dengan prosentase peningkatan kuat tekan terhadap benda uji S100 yaitu mortar dengan pasir Samboja $100 \%$ pada umur beton 28 hari adalah $-7,22 \%$; $-17,54 \%$; $8,26 \% ; 2,06 \% ;-7,22 \% ;-21,65 \%$; $-20,63 \%$; $2,06 \% ;-34,02 \%$ dan $-13,41 \%$ masing-masing untuk benda uji mortar S90, S80, S70, S60, P50, P60, P70, P80, P90 dan P100.

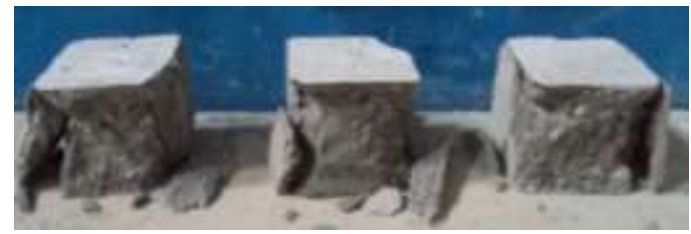

(a). Umur 14 hari

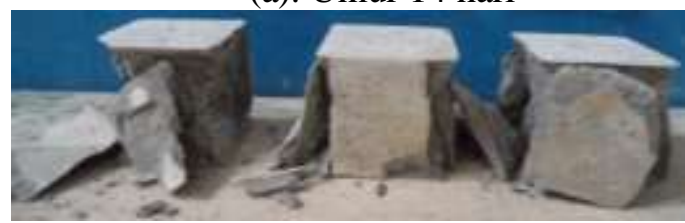

(b). Umur 28 hari

Gambar 1.Benda Uji Mortar yang Telah diuji Tekan

Gambar 2 menunjukan tren dari kuat tekan mortar. Dari grafik diperoleh persamaan $y=0,016 x^{2}-1,762 x+56$. dengan untuk mortar umur 14 hari dan $y=-0,0084 x^{2}+1,0649 x+51$.

dengan $\quad R^{2}=0,1$ untuk mortar umur 28 hari.

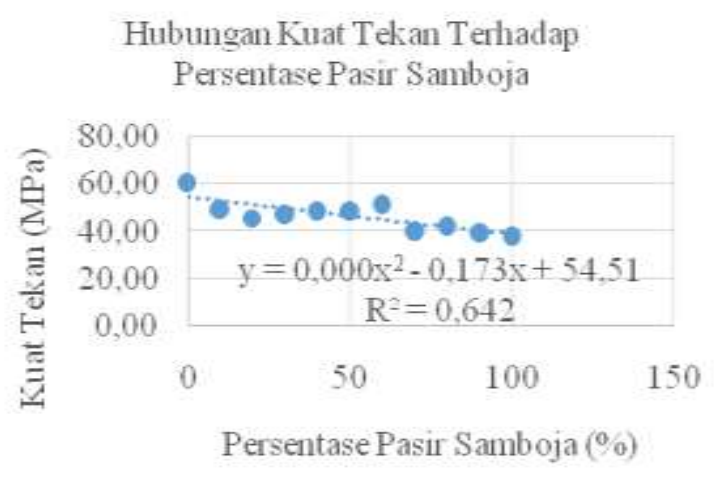

(a) Umur 14 Hari

Hubungan Kuat Tekan Terhadap Persentase Pasir Samboja

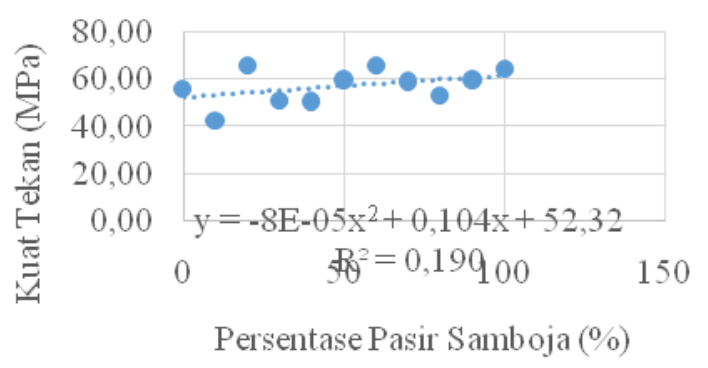

(b) Umur 28 hari

Gambar 2. Grafik Tren Kuat Tekan Mortar

Dari tren yang ada maka diperoleh nilai kuat tekan teoritis adalah sebagai berikut:

Tabel 4. Nilai Kuat Tekan Mortar

\begin{tabular}{ccccc}
\hline & \multicolumn{2}{c}{ Umur 14 hari } & \multicolumn{2}{c}{ Umur 28 hari } \\
\cline { 2 - 5 } $\begin{array}{c}\text { Benda } \\
\text { Uji }\end{array}$ & $\begin{array}{c}\text { Kuat } \\
\text { Tekan } \\
\text { Penguji } \\
\text { an } \\
(\mathrm{MPa})\end{array}$ & $\begin{array}{c}\text { Kuat } \\
\text { Tekan } \\
\text { Teoritis } \\
(\mathrm{MPa})\end{array}$ & $\begin{array}{c}\text { Kuat } \\
\text { Tekan } \\
\text { Penguji } \\
\text { an } \\
(\mathrm{MPa})\end{array}$ & $\begin{array}{c}\text { Kuat } \\
\text { Tekan } \\
\text { Teoritis } \\
(\mathrm{MPa})\end{array}$ \\
\hline P100 & 60,61 & 56,257 & 56 & 52,328 \\
P90 & 49,24 & 40,237 & 42,67 & 53,368 \\
P80 & 45,45 & 27,417 & 66 & 54,392 \\
P70 & 46,97 & 17,797 & 51,33 & 55,4 \\
P60 & 48,48 & 11,377 & 50,67 & 56,392 \\
P50 & 48,48 & 8,157 & 60 & 57,368 \\
S60 & 51,52 & 8,137 & 66 & 58,328 \\
S70 & 40,15 & 11,317 & 59,33 & 59,272 \\
S80 & 42,42 & 17,697 & 53,33 & 60,2 \\
S90 & 39,39 & 27,277 & 60 & 61,112 \\
S100 & 37,88 & 40,057 & 64,67 & 62,008 \\
\hline
\end{tabular}

Berdasarkan tabel 4 diatas maka diperoleh nilai kuat tekan hasil pengujian dan nilai teoritis tertinggi adalah untuk benda uji 
mortar P100 sebesar 60,61 MPa dan 56,257 MPa. Ini berarti bahwa benda uji mortar dengan gabungan pasir Palu 100\% dan pasir Samboja 0\% memberikan nilai kuat tekan mortar tertinggi pada umur 14 hari. Nilai kuat tekan umur 28 hari benda uji mortarf, nilai teoritis tertinggi 62,008 $\mathrm{MPa}$ untuk benda uji S100 berdasarkan hasil pengujian kuat tekan tertinggi sebesar $66 \mathrm{MPa}$ pada benda uji S60.

Hasiluji kuat tekan silinder beton dapat dilihat pada tabel 5 .

Tabel 5.Peningkatan Kuat Tekan Silinder Beton

\begin{tabular}{ccccc}
\hline & \multicolumn{2}{c}{ Umur 14 hari } & \multicolumn{2}{c}{ Umur 28 hari } \\
\cline { 2 - 5 } $\begin{array}{c}\text { Benda } \\
\text { Uji }\end{array}$ & $\begin{array}{c}\text { Kuat } \\
\text { Tekan } \\
\text { Pengujian } \\
(\mathrm{MPa})\end{array}$ & $\begin{array}{c}\text { Pening } \\
\text { katan } \\
\text { Kuat } \\
\text { Tekan } \\
(\%)\end{array}$ & $\begin{array}{c}\text { Kuat } \\
\text { Tekan } \\
\text { Pengujian } \\
(\text { MPa })\end{array}$ & $\begin{array}{c}\text { Pening } \\
\text { katan } \\
\text { Kuat } \\
\text { Tekan } \\
(\%)\end{array}$ \\
\hline P100 & 26,38 & 51,85 & 28,87 & $-1,3$ \\
P90 & 29,6 & 70,37 & 28,12 & $-3,86$ \\
P80 & 30,88 & 77,78 & 31,14 & 6,46 \\
P70 & 29,52 & 69,95 & 31,14 & 6,46 \\
P60 & 29,6 & 70,37 & 27,18 & $-7,08$ \\
P50 & 23,16 & 33,33 & 31,33 & 7,11 \\
S60 & 23,16 & 33,33 & 30,57 & 4,51 \\
S70 & 24,66 & 41,98 & 30,2 & 3,25 \\
S80 & 22,95 & 32,1 & 28,5 & $-2,56$ \\
S90 & 22,09 & 27,16 & 30,95 & 5,81 \\
S100 & 17,37 & - & 29,25 & - \\
\hline
\end{tabular}

Dari hasil uji tekan silinder umur 14 hari maka diperoleh nilai kuat tekan silinder terbesar dari hasil pengujian adalah untuk benda uji P80 yaitu benda uji dengan persentase pasir Palu adalah $80 \%$ dan pasir Samboja 20\%. Besar kuat tekan yang dihasilkan adalah $30,88 \mathrm{MPa}$ dengan peningkatan kuat tekan sebesar $77,78 \%$ terhadap benda uji S100 (benda uji silinder dengan $100 \%$ pasir Samboja tanpa pasir Palu).

Dari hasil uji tekan silinder umur 28 hari maka diperoleh nilai kuat tekan terbesar dari hasil pengujian adalah untuk benda uji P50 yaitu benda uji dengan persentase pasir Palu adalah 50\% dan pasir Samboja 50\%. Besar kuat tekan yang dihasilkan adalah $31,33 \mathrm{MPa}$ dengan peningkatan kuat tekan sebesar $7,11 \%$ terhadap benda uji S100 (benda uji dengan $100 \%$ pasir Samboja tanpa pasir Palu).
Nilai kuat tekan rata-rata beton umur 14 hari adalah 26,38 $\mathrm{MPa} ; 29,60 \mathrm{MPa} ; 30,88$ $\mathrm{MPa}$; 29,52 MPa; 29,60 MPa; 23,16 MPa; 23,16 MPa; 24,66 MPa;22,95 MPa; 22,09 MPa dan 17,37 MPa masing-masing untuk benda uji mortar P100, P90, P80, P70, P60, P50, S60, S70, S80, S90 dan S100.

Dengan prosentase peningkatan kuat tekan terhadap benda uji S100 yaitu beton dengan pasir Samboja $100 \%$ pada umur beton 14 hari adalah 27,16\%; 32,10\%; $41,98 \%$; 33,33\%; 33,33\%; 70,37\%; 69,95\%; $77,78 \% ; 70,37 \%$ dan $51,85 \%$ masing-masing untuk benda uji mortar S90, S80, S70, S60, P50, P60, P70, P80, P90 dan P100.

Nilai kuat tekan rata-rata beton umur 28 hari adalah 28,87 MPa; 28,12 $\mathrm{MPa}$; 31,14 $\mathrm{MPa}$; 31,14 MPa; 27,18 MPa; 31,33 MPa; 30,57 $\mathrm{MPa} ; 30,20 \mathrm{MPa} ; 28,50 \mathrm{MPa} ; 30,95$ MPa dan 29,25 MPa masing-masing untuk benda uji mortar P100, P90, P80, P70, P60, P50, S60, S70, S80, S90 dan S100.

Dengan prosentase peningkatan kuat tekan terhadap benda uji $\mathrm{S} 100$ yaitu silinderdengan pasir Samboja 100\% pada umur beton 28 hari adalah $5,81 \%$; $-2,56 \%$; $3,25 \% ; \quad 4,51 \% ; \quad 7,11 \% ; \quad-7,08 \% ; \quad 6,46 \%$; $6,46 \% ;-3,86 \%$ dan $-1,30 \%$ masing-masing untuk benda uji silinder S90, S80, S70, S60, P50, P60, P70, P80, P90 dan P100.

Gambar 3 adalah silinder beton yang telah diuji tekan.

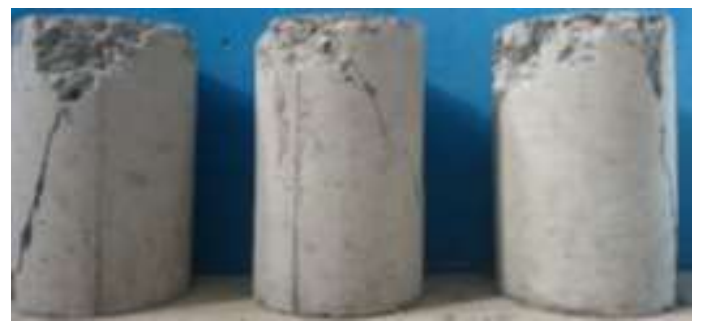

(a). Umur 14 hari

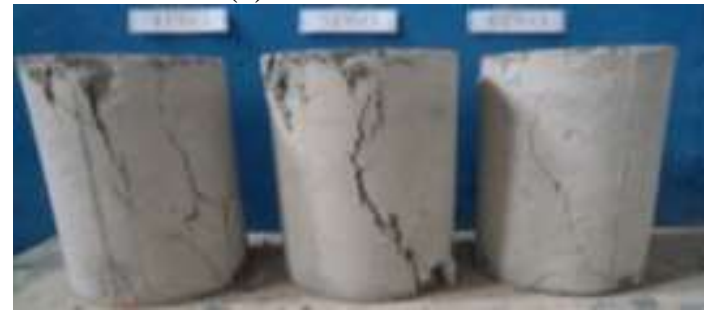

(b) Umur 28 hari

Gambar 3.Benda Uji Silinder yang Telah diuji Tekan

Dari grafik pada gambar 4, diperoleh persamaan

$$
Y=-0,1387 x^{2}+0,619 x+28
$$


Dengan $\mathrm{R}^{2}=0,7$ untuk umur 14 hari dan $\mathrm{y}=0,0052 \mathrm{x}^{3}-0,1334 \mathrm{x}^{2}+1,0117 \mathrm{x}+27,767$ dengan $R=0.07$ untuk umur 28 hari.

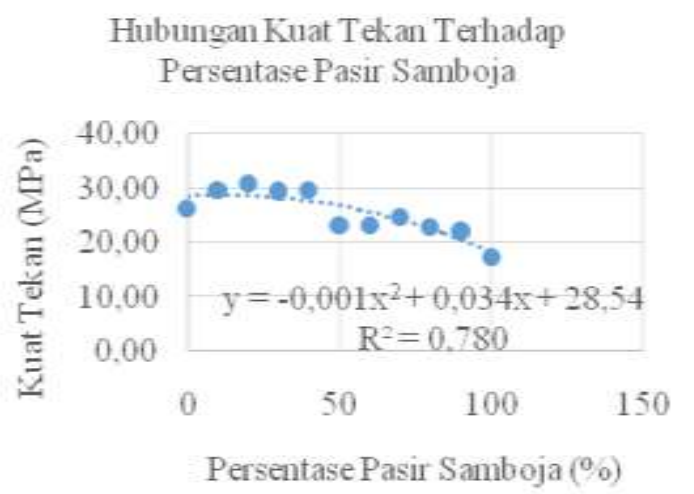

(a) Umur 14 hari

Hubungan Kuat Tekan Terhadap Persentase Pasir Samboja

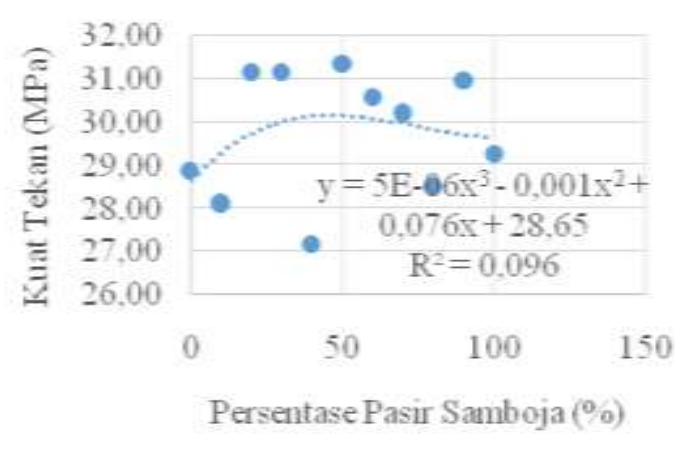

(b) Umur 28 hari

Gambar 4. Grafik Tren Kuat Tekan SilinderBeton

Dari tren yang ada maka diperoleh nilai kuat tekan teoritis adalah sebagai berikut:

Tabel 6. Nilai Kuat Tekan Silinder Beton

\begin{tabular}{ccccc}
\hline & \multicolumn{2}{c}{ Umur 14 hari } & \multicolumn{2}{c}{ Umur 28 hari } \\
\cline { 2 - 5 } Benda & $\begin{array}{c}\text { Kuat } \\
\text { Tekan } \\
\text { Uji } \\
\text { Penguji } \\
\text { an } \\
\text { (MPa) }\end{array}$ & $\begin{array}{c}\text { Kuat } \\
\text { Tekan } \\
\text { Teoritis } \\
(\mathrm{MPa})\end{array}$ & $\begin{array}{c}\text { Kuat } \\
\text { Tekan } \\
\text { Pengujia } \\
\text { n }(\mathrm{MPa})\end{array}$ & $\begin{array}{c}\text { Kuat } \\
\text { Tekan } \\
\text { Teoritis } \\
(\mathrm{MPa})\end{array}$ \\
\hline P100 & 26,38 & 28,544 & 28,87 & 28,651 \\
P90 & 29,6 & 28,746 & 28,12 & 29,296 \\
P80 & 30,88 & 28,668 & 31,14 & 29,731 \\
P70 & 29,52 & 28,31 & 31,14 & 29,986 \\
P60 & 29,6 & 27,672 & 27,18 & 30,091 \\
P50 & 23,16 & 26,754 & 31,33 & 30,076 \\
S60 & 23,16 & 25,556 & 30,57 & 29,971 \\
S70 & 24,66 & 24,078 & 30,2 & 29,806 \\
\hline
\end{tabular}

Lanjutan Tabel 6. Nilai Kuat Tekan Silinder Beton

\begin{tabular}{ccccc}
\hline & \multicolumn{2}{c}{ Umur 14 hari } & \multicolumn{2}{c}{ Umur 28 hari } \\
\cline { 2 - 5 } $\begin{array}{c}\text { Kuat } \\
\text { Benda } \\
\text { Uji }\end{array}$ & $\begin{array}{c}\text { Tekan } \\
\text { Penguji } \\
\text { an } \\
\text { (MPa) }\end{array}$ & $\begin{array}{c}\text { Kuat } \\
\text { Tekan } \\
\text { Teoritis } \\
(\mathrm{MPa})\end{array}$ & $\begin{array}{c}\text { Kuat } \\
\text { Tekan } \\
\text { Pengujia } \\
\text { n (MPa) }\end{array}$ & $\begin{array}{c}\text { Kuat } \\
\text { Tekan } \\
\text { Teoritis } \\
(\mathrm{MPa})\end{array}$ \\
\hline P100 & 26,38 & 28,544 & 28,87 & 28,651 \\
P90 & 29,6 & 28,746 & 28,12 & 29,296 \\
P80 & 30,88 & 28,668 & 31,14 & 29,731 \\
P70 & 29,52 & 28,31 & 31,14 & 29,986 \\
P60 & 29,6 & 27,672 & 27,18 & 30,091 \\
P50 & 23,16 & 26,754 & 31,33 & 30,076 \\
S60 & 23,16 & 25,556 & 30,57 & 29,971 \\
S70 & 24,66 & 24,078 & 30,2 & 29,806 \\
\hline
\end{tabular}

Berdasarkan tabel 6 diatas maka diperoleh nilai kuat tekan teoritis tertinggi umur 14 hari adalah untuk benda uji silinder P90 sebesar 28,746 MPa. Ini berarti bahwa benda uji mortar dengan gabungan pasir Palu 90\% dan pasir Samboja 10\% memberikan nilai kuat tekan silinder tertinggi.

Nilai kuat tekan teoritis tertinggi pada umur 28 hari adalah untuk benda uji silinder P60 sebesar 30,091 MPa. Ini berarti bahwa benda uji mortar dengan gabungan pasir Palu $60 \%$ dan pasir Samboja $40 \%$ memberikan nilai kuat tekan beton tertinggi.

\section{KESIMPULAN DAN SARAN Kesimpulan}

Dari hasil penelitian bahwa proporsi pasir Samboja yang memenuhi kriteria agregat halus dalam campuran beton adalah dibawah 70\% dengan MHB 1,64 mendekati zona 4 (pasir Agak Halus). Benda uji P50 dengan proporsi pasir Palu sebesar 50\% dan pasir Samboja sebesar 50\% memberikan nilai kuat tekan beton terbaik pada umur 28 hari yaitu 31,33 MPa dengan peningkatan kuat tekan sebesar 7,11\% terhadap S100 dan jika ditinjau dari tren kuat tekan yang terjadi adalah perpaduan pasir Palu dan pasir Samboja memberikan nilai yang baik pada P50 dan P60.

\section{Saran}

Saran dari penelitian ini berupa penelitian lanjutan tentang kombinasi pasir 
Samboja dan pasir Palu dengan variasi ukuran pasir palu, mengingat banyaknya variasi dari pasir Palu.

\section{DAFTAR PUSTAKA}

Karmila Achmad, 2015. Pasir Kandilo dan Kerikil Petangis sebagai Material Lokal Tanah Grogot dalam Campuran Beton. Media Teknik Sipil Vol. 13 No. 2.

Sara WR, Karmila A, 2015. Local Material Sand in East Kalimantan: Utilization with Fiber Reinforced Polymer Jacketing as an Effort to Increase the Concrete Strength. Jurnal Teknologi Terpadu, vol. 3 no. 2

Sunarno. 2012. Penggunaan Pasir Samboja dan Kerikil dari Palu sebagai Bahan Pembuatan Beton Normal. Jurnal Ilmiah Politeknik Balikpapan.

Mulyono, Tri. 2003. Teknologi Beton. Yogyakarta: Penerbit Andi.

Badan Standardisasi Nasional. 2000. SNI 03-2834-2000Tata Cara Pembuatan Rencana Campuran 